\title{
Management of hepatocellular adenoma during pregnancy
}

\author{
Johanna E. Noels ${ }^{1}$, Susanna M. van Aalten ${ }^{1}$, Dirk J. van der Windt ${ }^{1}$, Niels F.M. Kok ${ }^{1}$, \\ Rob A. de Man ${ }^{2}$, Turkan Terkivatan ${ }^{1}$, Jan N.M. IJzermans ${ }^{1, *}$ \\ ${ }^{1}$ Department of Surgery, Erasmus Medical Centre, Rotterdam, The Netherlands; ${ }^{2}$ Department of Hepatogastroenterology, \\ Erasmus Medical Centre, Rotterdam, The Netherlands
}

\begin{abstract}
Background \& Aims: Hepatocellular adenoma in pregnant women requires special considerations because of the risk of hormone induced growth and rupture. To prevent these potential lethal complications, pregnancy is either often discouraged or the surgical resection of large adenomas is recommended. It may be questioned whether it is justified to deny a young woman a pregnancy, as the biological behaviour of hepatocellular adenoma may be less threatening than presumed. In this study we establish the management of hepatocellular adenoma during pregnancy based on our own experience and literature.

Methods: Twelve women with documented hepatocellular adenoma were closely monitored during a total of 17 pregnancies between 2000 and 2009. Their files were reviewed.

Results: In four cases, hepatocellular adenomas grew during pregnancy, requiring a Caesarean section in one patient (two pregnancies) at 36 and 34 weeks because of an assumed high risk of rupture. In one case radiofrequency ablation therapy was applied in the first trimester to treat a hormone sensitive hepatocellular adenoma, thereby excluding potential growth later in pregnancy. No intervention was performed in the other 14 cases and all pregnancies had an uneventful course with a successful maternal and fetal outcome.

Conclusions: A "wait and see" management may be advocated in pregnant women presenting with a hepatocellular adenoma. In women with large tumours or in whom hepatocellular adenoma had complicated previous pregnancies, surgical resection may be recommended. In women with smaller adenomas it may no longer be necessary to discourage pregnancy.

(c) 2010 European Association for the Study of the Liver. Published by Elsevier B.V. All rights reserved.
\end{abstract}

\section{Introduction}

Hepatocellular adenoma (HCA) is an uncommon benign tumour of the liver that occurs particularly in women during their reproductive years. The annual incidence rate of HCA is approximately $1-1.3$ per $1,000,000$ in women who have never used oral contraceptives (OC), compared to 30-40 per million in long-term users $[1,2]$. Thus, most HCA's are associated with the use of OC [3-5], an association which was first described in 1973 [3]. Other conditions associated with the presence of HCA have been described, including anabolic steroids, glycogen storage disease I and III and pregnancy [6-13]. Most likely the association of HCA and pregnancy is due to the increased levels of steroid hormones $[14,15]$. The presence of HCA can be complicated by hormone induced growth and subsequently, spontaneous haemorrhagic rupture that may threaten the life of both mother and child.

A growing or bleeding adenoma may present with persistent or acute severe pain localized in the upper right quadrant and in the epigastric region. Its presentation can be difficult to differentiate from more common aetiologies of abdominal pain in pregnancy, like preeclampsia, Haemolysis Elevated Liver enzymes and Low Platelets (HELLP) syndrome or non-obstetric pathology like appendicitis, gallbladder disease, biliary pancreatitis, or pulmonary embolism [16]. This differential diagnosis may lead to a diagnostic delay. Early detection of HCA and a correct management of these patients are highly important, since several manuscripts documented high maternal and fetal risks in case of a ruptured HCA during pregnancy with a reported maternal and fetal mortality rate of $44 \%$ and $38 \%$, respectively [17]. In the last decennium, the introduction and widespread use of highly advanced image modalities have probably decreased the doctors' delay in the diagnosis of HCA and the associated maternal and fetal mortality risk might be reduced significantly. No ruptures associated with gestation were reported in tumours less than $6.5 \mathrm{~cm}$ in size [17]. In non pregnant women haemorrhage has been documented in a tumour of $4.5 \mathrm{~cm}$ in size but is most commonly seen in tumours greater than $10 \mathrm{~cm}$ [17]. The risk of rupture is highest during the third trimester, most likely due to the cumulating level of estrogens and an increase in hyperdynamic circulation combined with an increase in vascularity of the liver with growth of the adenoma [17]. In the postpartum period, the risk of bleeding seems to be high as well; this can be explained by the sudden withdrawal of estrogens after delivery that may cause a sudden massive regression of the tumour leading to haemorrhage [17]. Because of the unpredictable behaviour of
Received 6 January 2010; received in revised form 24 June 2010; accepted 7 July 2010 *Corresponding author. Address: Department of Surgery, Erasmus MC Rotterdam, P.O. Box 2040, 3000 CA Rotterdam, The Netherlands. Tel.: +31 (0)10 463 3733; fax: 31 (0)10 4635307.

E-mail address: j.jzermans@erasmusmc.nl (J.N.M. IJzermans).

Abbreviations: HCA, hepatocellular adenoma; OC, oral contraceptives; HELLP, haemolysis elevated liver enzymes and low platelets; RFA, radiofrequency ablation. 


\section{Research Article}

Table 1. Patient characteristics, diagnosis and management.

\begin{tabular}{|c|c|c|c|c|c|c|}
\hline $\begin{array}{l}\text { Case } \\
\text { no. }\end{array}$ & Age & $\begin{array}{l}\text { Presentation before } \\
\text { pregnancy }\end{array}$ & $O C$ & Diagnosis & $\begin{array}{l}\text { Management before } \\
\text { pregnancy }\end{array}$ & $\begin{array}{l}\text { Course of HCA after } \\
\text { discontinuation OC }\end{array}$ \\
\hline 1 & 29 & $\begin{array}{l}\text { Symptomatic (bleeding, } \\
\text { haemodynamically stable) }\end{array}$ & Yes & 3 HCA's, all $<5.0 \mathrm{~cm}$ & $\begin{array}{l}\text { Elective surgery; } \\
\text { laparoscopic } \\
\text { segment } 2 / 3 \text { resection. } \\
\text { Discontinuation OC }\end{array}$ & $\begin{array}{l}\text { No regression } \\
\text { or growth of } \\
\text { lesions }\end{array}$ \\
\hline 2 & 37 & $\begin{array}{l}\text { No complaints; incidental } \\
\text { finding on US }\end{array}$ & Yes & $1 \mathrm{HCA},<5.0 \mathrm{~cm}$ & $\begin{array}{l}\text { Conservative. } \\
\text { Discontinuation OC }\end{array}$ & Regression of lesion \\
\hline 3 & 30 & $\begin{array}{l}\text { Symptomatic (bleeding, } \\
\text { haemodynamically stable) }\end{array}$ & Yes & Multiple HCA's, one $>5.0 \mathrm{~cm}$ & $\begin{array}{l}\text { Conservative. } \\
\text { Discontinuation OC }\end{array}$ & $\begin{array}{l}\text { Unknown; stopped OC } \\
\text { before HCA was } \\
\text { diagnosed }\end{array}$ \\
\hline 4 & 28 & $\begin{array}{l}\text { Unspecific complaints; } \\
\text { incidental finding on US }\end{array}$ & Yes & Multiple HCA's, all $<5.0 \mathrm{~cm}$ & $\begin{array}{l}\text { Conservative. } \\
\text { Discontinuation OC } \\
\text { Weight reduction }\end{array}$ & Regression of lesions \\
\hline 5 & 25 & $\begin{array}{l}\text { Unspecific complaints; } \\
\text { incidental finding on US }\end{array}$ & Yes & $\begin{array}{l}3 \text { lesions, atypical FNH/ } \\
\text { adenoma, all }<5.0 \mathrm{~cm}\end{array}$ & $\begin{array}{l}\text { Conservative. } \\
\text { Discontinuation OC }\end{array}$ & Unknown \\
\hline 6 & 41 & $\begin{array}{l}\text { No complaints; incidental } \\
\text { finding on US }\end{array}$ & Yes & 3 HCA's, one $>5.0 \mathrm{~cm}$ & $\begin{array}{l}\text { Elective surgery, } \\
\text { segment } 4 \text { resection }\end{array}$ & $\begin{array}{l}\text { No regression or } \\
\text { growth of lesions }\end{array}$ \\
\hline 7 & 33 & $\begin{array}{l}\text { Presentation during } \\
\text { pregnancy; symptomatic } \\
\text { (pain right flank) }\end{array}$ & Yes & $1 \mathrm{HCA},<5.0 \mathrm{~cm}$ & $\begin{array}{l}\text { Before } 2^{\text {nd }} \text { pregnancy RFA; } \\
\text { segment } 4 \mathrm{a} \text {. } \\
\text { Discontinuation OC }\end{array}$ & $\begin{array}{l}\text { Unknown; stop of OC } \\
\text { before } \\
\text { HCA was diagnosed }\end{array}$ \\
\hline 8 & 23 & $\begin{array}{l}\text { Unspecific complaints } \\
\text { (abdominal pain); } \\
\text { diagnosis elsewhere }\end{array}$ & Yes & 2 HCA's, one $>5.0 \mathrm{~cm}$ & $\begin{array}{l}\text { Elective embolisation. } \\
\text { Discontinuation OC }\end{array}$ & Growth of lesions \\
\hline 9 & 31 & $\begin{array}{l}\text { Unspecific complaints; } \\
\text { incidental findings on US }\end{array}$ & No & Multiple HCA's, one $>5.0 \mathrm{~cm}$ & Conservative. & - \\
\hline 10 & 35 & $\begin{array}{l}\text { Symptomatic (bleeding, } \\
\text { haemodynamically stable) }\end{array}$ & Yes & Multiple HCA's, all $<5.0 \mathrm{~cm}$ & $\begin{array}{l}\text { Elective surgery; } \\
\text { segment } 3 / 6 \\
\text { resection. } \\
\text { Discontinuation OC }\end{array}$ & $\begin{array}{l}\text { No regression or } \\
\text { growth of lesions }\end{array}$ \\
\hline 11 & 36 & $\begin{array}{l}\text { Unspecific complaints; } \\
\text { incidental findings on CT }\end{array}$ & Yes & $1 \mathrm{HCA},<5.0 \mathrm{~cm}$ & $\begin{array}{l}\text { Conservative. } \\
\text { Discontinuation OC }\end{array}$ & Regression of lesion \\
\hline 12 & 28 & $\begin{array}{l}\text { Unspecific complaints; } \\
\text { incidental findings on US }\end{array}$ & Yes & 2 HCA's, one $>5.0 \mathrm{~cm}$ & $\begin{array}{l}\text { Conservative. } \\
\text { Discontinuation OC }\end{array}$ & Regression of lesions \\
\hline
\end{tabular}

US = ultrasound

HCA and high maternal and fetal mortality of a ruptured HCA during pregnancy women with a large HCA or a growing and hormone sensitive HCA are advised to avoid pregnancy by most experts (either incidental findings previous to a pregnancy or women who experienced complications of an adenoma during pregnancy) [2,15]. In addition, pregnancy itself limits the diagnostic modalities and interventions may be associated with greater risks in case of large adenomas [17].

At our centre, HCA's with a diameter of $5 \mathrm{~cm}$ or larger that do not show adequate regression after discontinuation of the use of OC are considered for invasive treatment before pregnancy [15]. We were able to study 12 patients from a prospectively acquired database who sustained HCA's of different sizes during a total number of 17 pregnancies.

\section{Patients and methods}

The Erasmus Medical Centre is a tertiary referral centre for focal liver lesions with an area of adherence of approximately 4 million people. From 2000 to 2009 all data of patients with HCA were recorded prospectively in a weekly multidisciplinary meeting attended by a radiologist, hepatologist, pathologist, and surgeon specialized in solid liver tumours. At the time of diagnosis every HCA patient was advised to discontinue the use of $\mathrm{OC}$ and to prevent pregnancy. If pregnancy would nevertheless occur, patients were strongly advised to contact our centre 


\section{JOURNAL OF HEPATOLOGY}

Table 2. Details of HCA with concern to pregnancy and follow-up after delivery.

\begin{tabular}{|c|c|c|c|c|c|}
\hline $\begin{array}{l}\text { Case } \\
\text { no. }\end{array}$ & $\begin{array}{l}\text { Pregnancy } \\
\text { no. }\end{array}$ & Growth & $\begin{array}{l}\text { Interventions during } \\
\text { pregnancy }\end{array}$ & Follow-up after delivery & Course of HCA's during follow-up \\
\hline 1 & 1 & No & None & Follow-up elsewhere & \\
\hline \multirow[t]{2}{*}{2} & 1 & No & None & 10 months & Regression, HCA hardly visible on last US \\
\hline & 2 & No & None & 8 months & Regression of lesion \\
\hline \multirow[t]{2}{*}{3} & 1 & Yes: $>5 \mathrm{~cm}$ & $\begin{array}{l}\text { C-section and } \\
\text { administration on IC- } \\
\text { unit after delivery. }\end{array}$ & 17 months & $\begin{array}{l}\text { Some regression of } 3 \text { HCA's, } \\
\text { remaining HCA's status quo. } \\
\text { No evidence of rupture. }\end{array}$ \\
\hline & 2 & $\begin{array}{l}\text { Yes: }>5 \mathrm{~cm} \text {, in } \\
\text { two tumours }\end{array}$ & C-section & Ongoing & $\begin{array}{l}\text { Some regression of HCA's on CT, } \\
\text { No evidence of rupture }\end{array}$ \\
\hline 4 & 1 & No & None & None & Unknown \\
\hline \multirow[t]{2}{*}{5} & 1 & Yes, but $<5 \mathrm{~cm}$ & None & 24 months & Regression of lesion \\
\hline & 2 & No & None & Ongoing & Unknown \\
\hline 6 & 1 & No & None & 3 months & On US no evidence of focal liver lesions \\
\hline \multirow[t]{2}{*}{7} & 1 & Yes: $>5 \mathrm{~cm}$ & None & Follow up elsewhere & Regression of lesion \\
\hline & 2 & $\begin{array}{l}\text { No: no tumour } \\
\text { after RFA }\end{array}$ & None & 5 months & $\begin{array}{l}\text { On US no evidence of focal liver } \\
\text { lesion }\end{array}$ \\
\hline \multirow[t]{2}{*}{8} & 1 & No & None & 10 months & $1 \mathrm{HCA}$ regression, $1 \mathrm{HCA}$ status quo ante \\
\hline & 2 & No & None & Ongoing & Unknown \\
\hline 9 & 1 & No & $\begin{array}{l}\text { RFA } 1^{\text {st }} \text { trimester; } \\
\text { segment } 6\end{array}$ & 48 months & $\begin{array}{l}1 \mathrm{HCA} \text { regression after RFA, } \\
\text { remaining HCA's status quo ante }\end{array}$ \\
\hline 10 & 1 & $\begin{array}{l}2^{\text {nd }} \text { trimester } \\
\text { minimal } \\
\text { regression }\end{array}$ & C-section & 16 months & $\begin{array}{l}\text { Regression, HCA hardly visible on last } \\
\text { MRI }\end{array}$ \\
\hline 11 * & 1 & Unknown & None & 8 months & Regression of lesion \\
\hline 12 & 1 & No & None & Ongoing & Unknown \\
\hline
\end{tabular}

US = ultrasound

In case No. 11 there was no monitoring of HCA in our hospital.

to evaluate growth of the tumour by the surgeon or hepatologist. Follow-up of the fetus was carried out by the gynaecologist on a regular basis. A gynaecologist was consulted only in those cases where a significant growth of the adenoma was observed and its management could influence pregnancy.

The patients described ( 12 of 183 patients with HCA) were diagnosed by contrast enhanced CT or MR imaging between January 2000 and December 2009. Until 2008 Gadolinium was the contrast agent of choice for MR imaging. In some cases, Gadolinium was followed by Resovist contrast for increased diagnostic certainty. After 2008, MultiHance was the contrast agent of choice for MR imaging.

During their pregnancy they were closely monitored by means of repetitive ultrasound and/or MR imaging. The frequencies of the measurements had no fixed time schedule and depend on the size and changes in the characteristics of the lesion. Their files were reviewed to evaluate presentation and time of presentation, use of OC, size and growth before and during pregnancy and postpartum, complications and management during pregnancy, gestation time and way of delivery, maternal and fetal outcome, and complications and management after delivery.

\section{Results}

Nearly all women (11 of 12 ) were diagnosed with HCA prior to their pregnancy. In one patient, HCA was diagnosed during pregnancy (Table 1). Eleven patients were using OC at the time of diagnosis, or had used $O C$ in the past. In four patients there had been a regression of HCA's after discontinuation of OC. One patient became pregnant before it was possible to evaluate her hormone sensitivity for the HCA. Another two patients stopped OC before HCA was diagnosed. In one patient there was growth of the HCA two and a half years after discontinuation of OC. No regression or growth of the HCA was noticed in three patients. Ten patients presented in the first trimester of pregnancy for monitoring of the HCA (Table 2). In one patient with multiple HCA's (case No. 3) there was serious concern about the risk of rupture of these lesions. One year before pregnancy she presented with an acute sensation of upper right quadrant pain, based on an intracapsular haemorrhage of an HCA. She withdrew from medical attention during the first trimester of her first pregnancy, but presented at the gynaecologist at 33 weeks gestation because of diabetes gravidarum. Until then, the patient was under surveillance at her general practitioner. At 33 weeks gestation, MR imaging, after ultrasound was performed, revealed a significant growth of the largest lesion from 32 to $75 \mathrm{~mm}$ (Fig. 1). Another lesion showed signs of haemorrhage that had been noticed 2 years ago. At that time the lesion was measured $60 \mathrm{~mm}$. This lesion measured $40 \mathrm{~mm}$ during her 33 weeks of gestation. To exclude any further risks, it was decided to deliver the child by means of a Caesarean section at 36 weeks with close postpartum monitoring of the mother at the Intensive Care Unit for several days because of an increased risk of haemorrhage. Despite our advice to 


\section{Research Article}
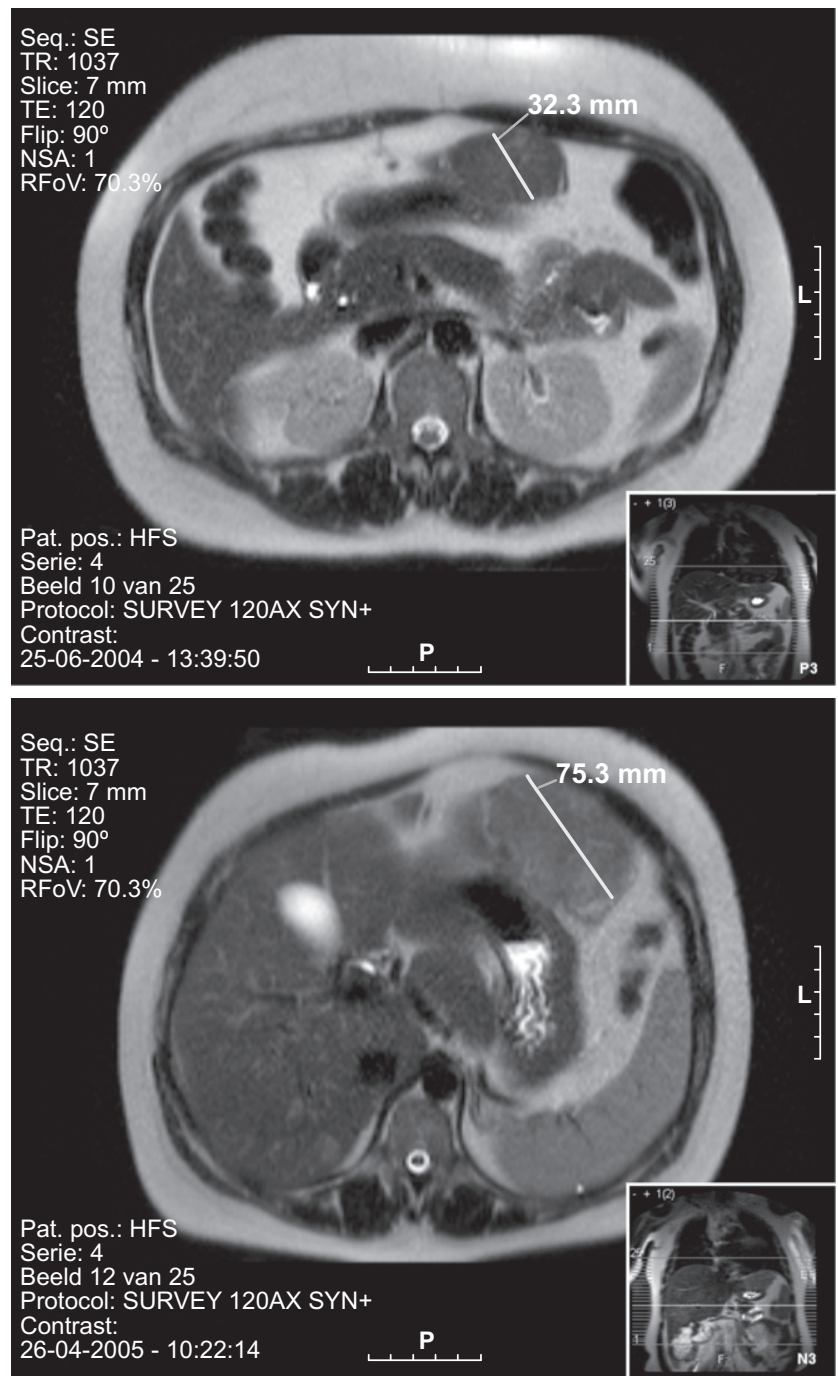

Fig. 1. MR-images of one of the adenomas (segment 2/3) of patient No. 3, nine months after diagnosis and discontinuation of OC's and in the 34th week of pregnancy. Due to pregnancy and the volume of the abdomen, the tumour was displaced in segment 2 and 3 cranially. The tumour shows significant growth.

prevent further pregnancies, this patient became pregnant a second time. In between her first and second pregnancy, there was a regression of the lesion from 75 to $40 \mathrm{~mm}$ demonstrated by MR imaging. During her second pregnancy, marked growth of the HCA's was noticed again, resulting in a Caesarean section at 33 weeks. Both children were born healthy. Two patients (case Nos. 5 and 7) showed growth in association with pregnancy and regression of the tumour postpartum (Figs. 2 and 3 ). In one patient (case No. 9), who wanted to keep her pregnancy, the tumour was treated with radiofrequency ablation (RFA) during the first trimester of her second pregnancy. The HCA showed regression during her pregnancy from $43 \times 35$ $\mathrm{mm}$ to $27 \times 19 \mathrm{~mm}$.

Maternal and fetal outcomes were excellent in all cases and none of the HCA's resulted in complications during pregnancy or after delivery.

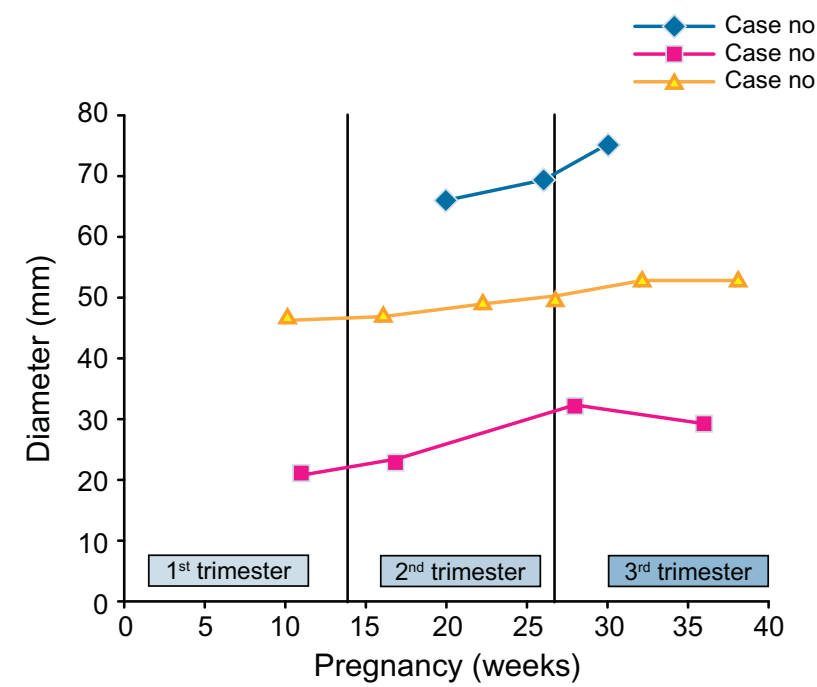

Fig. 2. Growth of the largest adenoma during pregnancy.

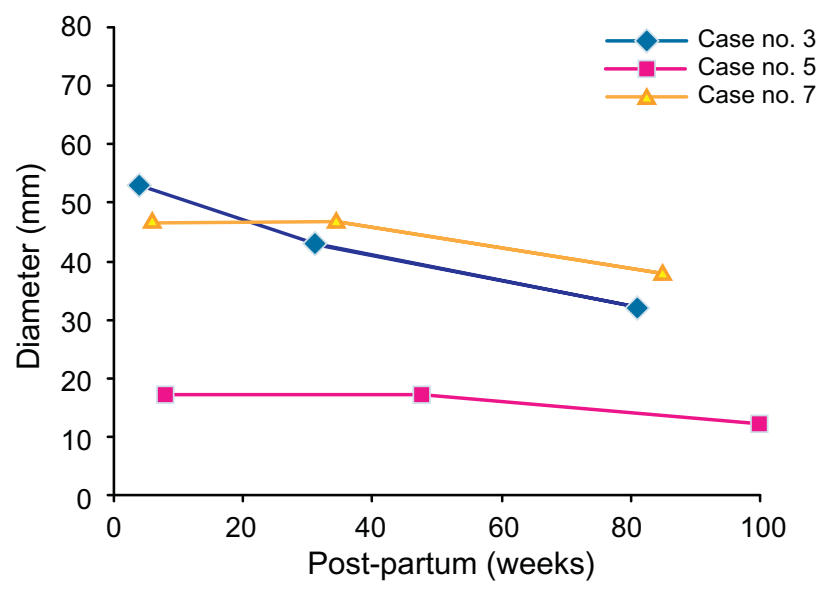

Fig. 3. Regression of the largest adenoma postpartum.

\section{Discussion}

The diagnosis of HCA may severely impact the life of a young fertile woman, in particular because of the overall agreed advice to avoid pregnancy. Literature on the course of HCA during pregnancy and recommended management is scarce. Some authors advocate that women with HCA should not get pregnant $[2,15]$. As to date we cannot identify precisely those at risk of complications. It is likely that only a small subgroup of patients may experience complications. We provide a small but unique series of women who were monitored meticulously during pregnancy. Most cases of HCA related to pregnancy described in the literature were presented during pregnancy or shortly postpartum. From the international literature between 1966 and 2003, Cobey et al. retrieved 26 cases of women presenting with HCA during pregnancy or early postpartum and proposed an algorithm for their diagnosis and management [17]. Presentation was acute and often dramatic with rupture of the adenoma in 16 women, and frequently with a delay in establishing the correct diagnosis, 


\section{JOURNAL OF HEPATOLOGY}

with high maternal and fetal mortality. An aggressive approach towards resection of HCA was advocated, especially for those greater than $5 \mathrm{~cm}$, based upon the high maternal and fetal mortality ( $44 \%$ and $38 \%$, respectively) for women presenting with HCA during pregnancy. Small adenomas were supposed to be managed by observation [17].

We have previously reported that more than half of the HCA's are discovered after the patient has sustained at least one pregnancy [18]. None of these patients have reported problems during their pregnancies. In the current small series, just one patient presented with a tumour growth of real concern and that demanded an invasive intervention during pregnancy. In addition, rupture or other complications of solitary or multiple HCA's did not occur during intensive follow-up.

Based on these data we believe that a plea for a less aggressive surgical approach towards HCA in pregnant women may be justified. Especially in small tumours $(<5 \mathrm{~cm})$ we propose close monitoring and we believe it can be safe to allow pregnancy. However, in some women in whom the growth of the HCA is substantial there is reason for concern. Some authors suggest a Caesarean section (C-section) for HCA given the tendency to rupture at term [17]. In our study three C-sections (two patients) were performed, without complications. In one case (No. 3) C-section was performed in consultation with the patient because of marked growth and an unknown risk of rupture of the HCA's. In the other patient (case No. 10) C-section was due to decelerations on the cardiotocography. All other patients had a normal delivery which was never complicated by the rupture of an HCA. Therefore, in our opinion, patients with HCA may deliver vaginally if there are no complicating factors, like perinatal problems.

Prognostic factors on rupture and malignant degeneration during pregnancy remain unknown until this moment. Women with HCA's must be informed about the possible risks before pregnancy. The literature on the management of HCA's during pregnancy is scarce due to the low incidence of HCA's in general $[2,15]$, and the low number of HCA's detected during pregnancy in particular. Growth of HCA in pregnant women requires special considerations for contemplating and timing possible interventions.

In the case an intervention is indicated, surgical resection as well as a minimal invasive approach may be considered, especially in smaller lesions. An intervention is safest in the 2nd trimester [14]. RFA is a minimally invasive technique, which is widely used for the treatment of patients with primary and secondary malignant tumours especially when resection is not an option. RFA is believed to be a relatively safe procedure in experienced hands with low mortality and morbidity [19-22]. In 2006, Fujita et al. reported a pregnant patient with a HCA that was treated by RFA during her 18th gestational week [23]. In our centre RFA is occasionally used as an alternative treatment in women with HCA. A disadvantage of RFA is that after ablation of the tumour there is no material for pathological analysis. When there is any doubt about the diagnosis, especially about the benign character of the tumour, the diagnosis should be confirmed first. If malignancy cannot be excluded, surgical resection is preferred. Selective arterial embolization can be used both as an elective treatment to reduce the size of the HCA as well as the initial emergency treatment in case of active bleeding of the HCA [24-26]. It is a minimal invasive and safe procedure compared to laparotomy and complications are rare. There are no large patient series, and especially in pregnant women with HCA there is little experience with the use of arterial embolization, although some authors suggest that it is a safe and effective treatment for HCA $[27,28]$. Since the risk of radiation exposure $[29,30]$ to the fetus is increased, especially before 26 weeks of gestation, we feel that selective arterial embolization should only be used as an emergency treatment when RFA or surgery are not a favourable option, for instance for more centrally located tumours that are hardly accessible for RFA.

In conclusion, based on our small but unique prospective series we propose not to discourage all women with HCA's from pregnancy. We hypothesize that pregnancy may be allowed in case of a known HCA under certain conditions such as size and after discussing the risk-benefit ratio with the patient. Women should be aware of the potential risks as an intervention may still be indicated during pregnancy, especially if the lesion is accessible for limited surgical resection or a percutaneous RFA. Close monitoring by liver ultrasound every 6 weeks may offer adequate information for surveillance of the hepatic lesion. In women who have large tumours or who have experienced complications of HCA in previous pregnancies, a negative advice against pregnancy is justified because of an increased risk of complications. In that case, surgical resection should be recommended before pregnancy. HCA in pregnant women implies special considerations, therefore, additional data from different centres for the risk of hormone induced growth and rupture of the adenoma during pregnancy are needed.

\section{Conflict of Interests}

The authors who have taken part in this study declare that they do not have anything to disclose regarding funding or conflict of interest with respect to this manuscript.

\section{Acknowledgements}

We thank the Department of Radiology of the Erasmus Medical Centre for the MR-images and Dr. Pleun Snel, gastro-enterologist, Slotervaart Ziekenhuis Amsterdam for his comment.

\section{References}

[1] Reddy KR, Schiff ER. Approach to a liver mass. Semin Liver Dis 1993;13:423-435

[2] Rooks JB, Ory HW, Ishak KG, Strauss LT, Greenspan JR, Hill AP, et al. Epidemiology of hepatocellular adenoma. The role of oral contraceptive use. JAMA 1979;242:644-648.

[3] Baum JK, Bookstein JJ, Holtz F, Klein EW. Possible association between benign hepatomas and oral contraceptives. Lancet 1973;2:926-929.

[4] Berg JW, Ketalaar RJ, Rose EF, Vernon RG. Letter: hepatomas and oral contraceptives. Lancet 1974;2:349-350.

[5] Stenwig AE, Solgaard T. Ruptured benign hepatoma associated with an oral contraceptive. A case report. Virchows Arch A Pathol Anat Histol 1975;367:337-343.

[6] Bianchi L. Glycogen storage disease I and hepatocellular tumours. Eur J Pediatr 1993;152 (Suppl. 1):S63-S70.

[7] Carrasco D, Prieto M, Pallardo L, Moll JL, Cruz JM, Munoz C, et al. Multiple hepatic adenomas after long-term therapy with testosterone enanthate. Review of the literature. J Hepatol 1985;1:573-578.

[8] Choi BY, Nguyen MH. The diagnosis and management of benign hepatic tumors. J Clin Gastroenterol 2005;39:401-412.

[9] Giannitrapani L, Soresi M, La Spada E, Cervello M, D’Alessandro N, Montalto G. Sex hormones and risk of liver tumor. Ann NY Acad Sci 2006;1089:228-236. 


\section{Research Article}

[10] Hussain SM, van den Bos IC, Dwarkasing RS, Kuiper JW, den Hollander J. Hepatocellular adenoma: findings at state-of-the-art magnetic resonance imaging, ultrasound, computed tomography and pathologic analysis. Eur Radiol 2006;16:1873-1886.

[11] Labrune P, Trioche P, Duvaltier I, Chevalier P, Odievre M. Hepatocellular adenomas in glycogen storage disease type I and III: a series of 43 patients and review of the literature. J Pediatr Gastroenterol Nutr 1997;24: 276-279.

[12] Santambrogio R, Marconi AM, Ceretti AP, Costa M, Rossi G, Opocher E. Liver transplantation for spontaneous intrapartum rupture of a hepatic adenoma. Obstet Gynecol 2009;113:508-510.

[13] van Aalten SM, Terkivatan T, de Man RA, van der Windt DJ, Kok NF, Dwarkasing R, et al. Diagnosis and treatment of hepatocellular adenoma in the Netherlands: similarities and differences. Dig Surg 2010;27:61-67.

[14] Parangi S, Levine D, Henry A, Isakovich N, Pories S. Surgical gastrointestinal disorders during pregnancy. Am J Surg 2007;193:223-232.

[15] Terkivatan T, de Wilt JH, de Man RA, IJzermans JN. Management of hepatocellular adenoma during pregnancy. Liver 2000;20:186-187.

[16] Angelini DJ. Obstetric triage revisited: update on non-obstetric surgical conditions in pregnancy. J Midwifery Womens Health 2003;48:111-118.

[17] Cobey FC, Salem RR. A review of liver masses in pregnancy and a proposed algorithm for their diagnosis and management. Am J Surg 2004;187: 181-191.

[18] van der Windt DJ, Kok NF, Hussain SM, Zondervan PE, Alwayn IP, de Man RA, IJzermans JN. Case-orientated approach to the management of hepatocellular adenoma. Br J Surg 2006;93:1495-1502.

[19] Atwell TD, Brandhagen DJ, Charboneau JW, Nagorney DM, Callstrom MR, Farrell MA. Successful treatment of hepatocellular adenoma with percutaneous radiofrequency ablation. AJR Am J Roentgenol 2005;184:828-831.

[20] Garrean S, Hering J, Helton WS, Espat NJ. A primer on transarterial, chemical, and thermal ablative therapies for hepatic tumors. Am J Surg 2007;194 79-88.
[21] Gazelle GS, Goldberg SN, Solbiati L, Livraghi T. Tumor ablation with radiofrequency energy. Radiology 2000;217:633-646.

[22] Livraghi T, Solbiati L, Meloni MF, Gazelle GS, Halpern EF, Goldberg SN. Treatment of focal liver tumors with percutaneous radio-frequency ablation: complications encountered in a multicenter study. Radiology 2003;226:441-451.

[23] Fujita S, Kushihata F, Herrmann GE, Mergo PJ, Liu C, Nelson D, et al. Combined hepatic resection and radiofrequency ablation for multiple hepatic adenomas. J Gastroenterol Hepatol 2006;21:1351-1354.

[24] Erdogan D, van Delden OM, Busch OR, Gouma DJ, van Gulik TM. Selective transcatheter arterial embolization for treatment of bleeding complications or reduction of tumor mass of hepatocellular adenomas. Cardiovasc Intervent Radiol 2007;30:1252-1258.

[25] Huurman VA, Stoot JH, van der Linden E, Terpstra OT, Schaapherder AF. Necrosis of a large hepatic tumor after hemorrhage and subsequent selective arterial embolization. World J Gastroenterol 2006;12:6059-6061.

[26] Stoot JH, van der Linden E, Terpstra OT, Schaapherder AF. Life-saving therapy for haemorrhaging liver adenomas using selective arterial embolization. $\mathrm{Br} \mathrm{J}$ Surg 2007;94:1249-1253.

[27] Stoot JH, van Roosmalen J, Terpstra OT, Schaapherder AF. Life-threatening hemorrhage from adenomas in the liver during pregnancy. Dig Surg 2006;23:155.

[28] Stain SC, Woodburn DA, Stephens AL, Katz M, Wagner WH, Donovan AJ. Spontaneous hepatic hemorrhage associated with pregnancy. Treatment by hepatic arterial interruption. Ann Surg 1996;224:72-78.

[29] Kal HB, Struikmans H. [Pregnancy and medical irradiation; summary and conclusions from the International Commission on Radiological Protection, Publication 84] Zwangerschap en straling; samenvatting en conclusies van Publicatie 84 van de International Commission on Radiological Protection. Ned Tijdschr Geneeskd 2002;146:299-303.

[30] Menias CO, Elsayes KM, Peterson CM, Huete A, Gratz BI, Bhalla S. CT of pregnancy-related complications. Emerg Radiol 2007;13:299-306. 